\title{
The Effects of Anthropogenic Pollutants on Primary Productivity in Mtwapa Creek Waters in Kilifi, Kenya
}

\author{
Mwamuye Tunje Pole ${ }^{1}$ Maarifa Ali Mwakumanya1, Najya Mohammed² \\ ${ }^{1}$ Department of Environmental Sciences, Pwani University, Kilifi, Kenya \\ ${ }^{2}$ Department of Chemistry and Biochemistry, Pwani University, Kilifi, Kenya \\ Email:maarifaali@yahoo.com
}

Received 20 October 2015; accepted 8 January 2016; published 11 January 2016

Copyright (C) 2016 by authors and Scientific Research Publishing Inc.

This work is licensed under the Creative Commons Attribution International License (CC BY).

http://creativecommons.org/licenses/by/4.0/

(c) (i) Open Access

\begin{abstract}
Marine environmental pollution from urban development, tourism industry and agricultural activities affects the quality of marine and aquatic life and humans. This study established the impact of anthropogenic activities on marine water nutrient loading and primary productivity at Mtwapa Creek in Kenya. Triplicate water samples were collected twice a month from seven (7) sites on the creek to determine the levels of concentration of the three nutrients; $\mathrm{PO}_{4}^{-}, \mathrm{NO}_{3}^{-}$and $\mathrm{NH}_{3}$ in creek waters. Samples were analyzed for nutrients level using the spectrophotometric method. Primary productivity as an indication of carbon assimilation was computed using the traditional Winkler method. Quantitative one-way Analysis of Variance was used to determine the variations between sampling sites while correlation analysis was computed to establish the relationship between nutrients and carbon levels. There was spatial and temporal fluctuation of nutrients levels on the creek; however the levels of nitrates were within the oligotrophic range. Phosphate levels were not significantly different throughout the sampling period, while Ammonia levels were very significantly high in the creek waters, implying active biochemical processes affecting primary productivity with phosphates greatly influencing carbon assimilation. Strategic land based management approaches should be instituted to reduce the discharge flow into the creek waters.
\end{abstract}

\section{Keywords}

Anthropogenic Pollutants, Nutrients, Oligotrophic Range, Dissolved Oxygen, ANOVA, Correlation Analysis 


\section{Introduction}

The Kenyan coastal creeks are vulnerable marine ecosystems to the impacts of both natural and anthropogenic disturbances of sedimentation from land erosion and eutrophication from nutrients discharges. The close proximity of the ecosystems to urban and agricultural areas has exposed creeks to pollution with potential to cause environmental impacts on the marine aquatic and human lives [1]. Creeks are among the most heavily polluted areas throughout the world with about $60 \%$ of the world's population living along creeks and estuaries [2]. Twenty two of the world's largest cities, including the City of New York are along creeks and estuaries [3]. Although great progress has been made in identifying nutrient pollutants and phases present in marine systems, there remains many questions regarding the origin and fate of compounds such as phosphates and polyphosphates [4]. Despite the creeks being vulnerable to the direct impacts of both natural and anthropogenic disturbances, there have been few efforts to continuously determine, monitor and understand the extent and nature of the impacts of land based pollution sources. Studies on the impact of sewage discharges into coastal marine waters and the characterization of nutrient enrichment in estuaries [5] [6] show that Mtwapa creek was on the higher mesotrophic levels compared to Tudor and Makupa creeks with increased nutrient trend down the estuarine systems. The high levels are attributed to human economic development [5].

Despite the creation of national institutions such as the National Environmental Management Authority (NEMA) and the enactment of national laws, supported by international conventions, the management of the coastal and marine environment is still a challenge. The governance structures for the protection of marine environment are however in many cases either weak, overlapped, inappropriate, or ineffective [7]. To investigate the influence of land based human activities on the productivity of the Mtwapa creek waters, inorganic nutrients; Nitrates, Phosphates and Ammonia were analyzed to determine the nutrients levels and primary productivity of the Creek phytoplankton. Phytoplankton productivity was determined as the rate of carbon fixation on the different sites on the creek. Primary productivity supports marine food web and photosynthetic activity fertilized by nitrogen, ammonia and phosphorous among other nutrients from land with ocean circulation redistributing biological productivity by transporting nutrients and phytoplankton far from the shores [8].

\section{Materials and Methods}

\subsection{The Study Site}

The study was conducted along Mtwapa Creek, on longitude $3^{\circ} 45^{\prime} \mathrm{OS}$ and $3^{\circ} 47^{\prime} \mathrm{OS}$ and latitudes $39^{\circ} 42^{\prime \prime} \mathrm{E}$ and $39^{\circ} 48^{\prime \prime} 0 \mathrm{E}$ (Figure 1). Mtwapa creek in Kilifi County, experiences an average annual rainfall of about $900 \mathrm{~mm}$ to $1100 \mathrm{~mm}$ and a mean annual temperatures of between $25^{\circ} \mathrm{C}$ and $30^{\circ} \mathrm{C}$. The creek is a popular tourist and fishing spots with inadequate environment conservation practices as witnessed by the presence of sewage outfalls of untreated waste water and surface runoff from agricultural areas during rainy season. The fishing and tourist activities are likely to impact on the creek water quality. Kilifi experiences a bimodal type of rainfall, with heavy long rains falling between April to July and short rains coming between the months of October to December. The rainfall surface runoff transport anthropogenic pollutants into the Creek. Sampling sites were confined within the marine water system to about $5 \mathrm{~km}$ from the mouth of the creek towards the upstream catchment. Analysis was done to determine the levels of Nitrates ( $\mu$ gatN/L), Ammonia $\left(\mu g a t N_{3}\right)$, Phosphates ( $\mu$ gatP/L) and marine Carbon assimilation $(\mathrm{mgC} / \mathrm{L})$, through primary productivity in marine waters.

\subsection{Sampling Design}

The study used a purposive sampling design with sampling sites identified about $10 \mathrm{~m}$ from the creek shoreline close to the source of pollution. The sampling sites were located near tourist hotel establishments, urban developments, conservation areas, the Shimo La Tewa prison waste water treatment plant and the small scale subsistence agricultural areas on the banks of the creeks, representing both the diffuse and point sources of effluents into the creeks. The sampling sites were identified using a Geographic Position System (GPS) for subsequent water sampling sessions. Sampling was done bimonthly for a period of six months from June 2011 to November 2011 to capture the dry and wet seasonal primary productivity dynamics on the creek.

Seven sampling stations were identified close to Maize farming area (S24), fish landing site (S25), natural drainage system upstream (S26), mariculture ponds and drainage outlet from Mtwapa town (S27), Shimo-LaTewa prison waste water plant outlet (S28), boatyard and restaurant (S29) and the Control site (SC30) located 


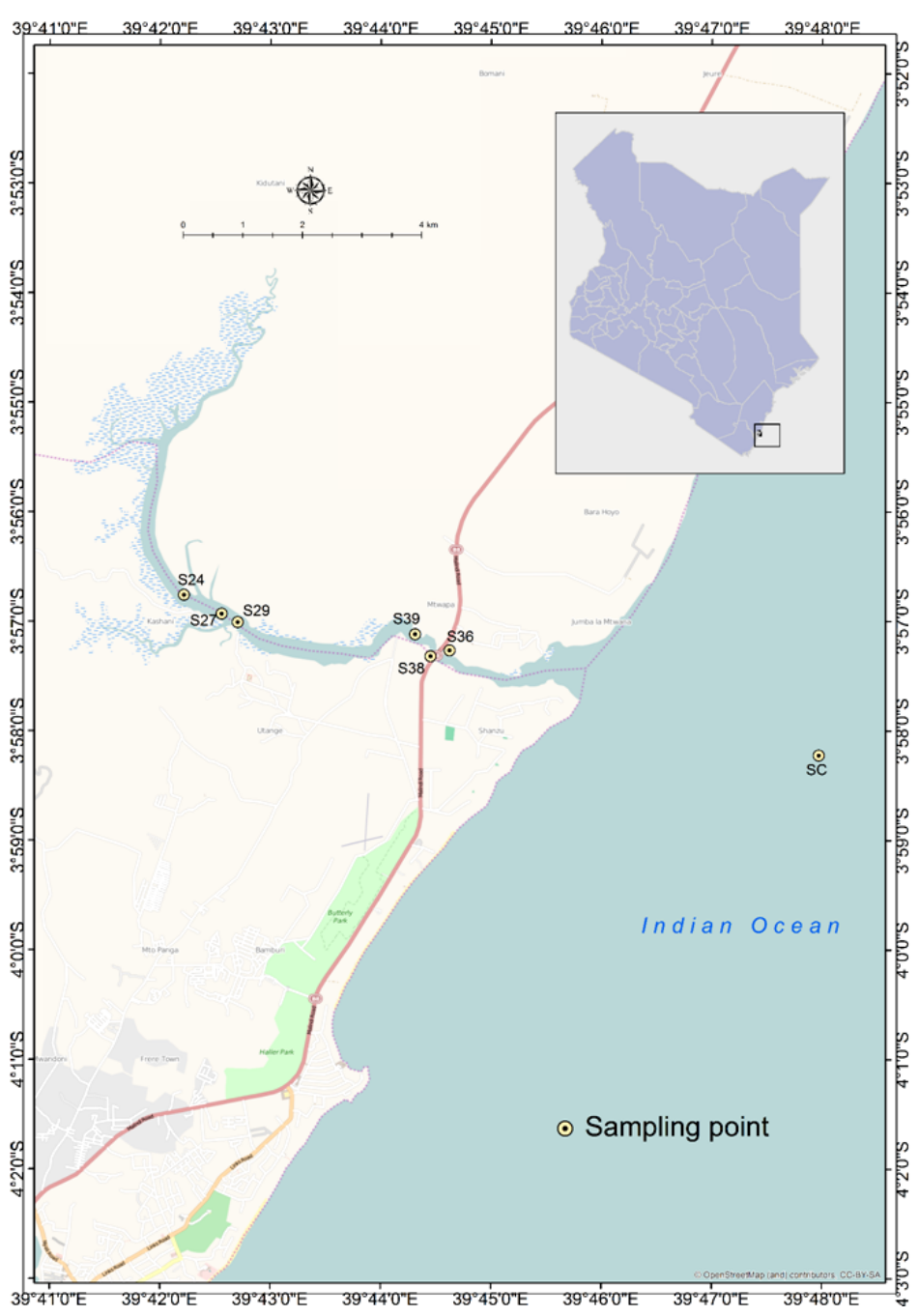

Figure 1. Sampling sites at Mtwapa creek.

in the open ocean about $4 \mathrm{~km}$ offshore, with minimum interactions with the land-based nutrients discharge. Triplicate surface water $(0.5 \mathrm{~m})$ samples in each site were collected in pre-cleaned polypropylene sample bottles and autoclaved at $121^{\circ} \mathrm{C} 12 \mathrm{Lbs} / \mathrm{sq}$ for $20 \mathrm{~min}$. The samples to determine the nutrients were fixed in situ with Mercury Chloride $(\mathrm{HgCl})$ to prevent any further biological activities, while samples for determination of carbon were fixed with a mixture of $0.4 \mathrm{ml}$ Manganese Sulphate $\left(\mathrm{MnSO}_{4}\right)$ and $0.4 \mathrm{ml}$ of Potassium Iodide (KI) to arrest photosynthesis.

The temporal and spatial variations of Nitrates ( $\mu$ gatN/L), Ammonia ( $\mu$ gat $\mathrm{NH}_{3}$ ), Phosphates ( $\mu$ gatP/L) and marine Carbon assimilation (mgC/L) were determined along the creek. A quantitative analysis of one way Analysis of Variance (ANOVA) at $\alpha=0.05$ was computed using the Statistical Analysis System (SAS) to determine the variations between and within sampling station means on each site and t-grouping of the means computed using a t-test at $\alpha=0.05$ significant level. A comparison of the levels of different nutrients with threshold levels for various nutrients was done against standard water quality variables criteria [9].

\subsection{Determination of Levels of Nutrients $\left(\mathrm{NO}_{3}^{-}, \mathrm{PO}_{4}^{-}\right.$and $\left.\mathrm{NH}_{3}\right)$ and Carbon Assimilations}

The reagents for preparation of calibration curve to be converted into levels of concentration of Nitrates, Ammonia and Phosphates were prepared using standard procedures [10]. The determination of levels of Nitrates, Ammonia and Phosphates were also done using standard colorimetric laboratory procedures (Ascorbic AcidMolybdate and Cadmium reduction methods) which produced coloured complexes spectrophotometrically [10], 
for the respective nutrients. Ex-situ primary productivity was determined using the traditional Winkler method [10] which determines the photosynthetic activity and subsequent measure of the biomass assimilation per unit time.

\section{Results}

\subsection{Variations in the Levels of Nitrates}

There was an increase in the level of the $\mathrm{NO}_{3}$ nutrients during the wet season (June to August) with the month of August 2011 recording the highest levels. The control station (SC30) (Table 1) recorded the lowest levels of $\mathrm{NO}_{3}$ nutrients. However, between September and November 2011, the nitrates levels generally decreased depicting the dry season levels. The variations in the nitrates levels in the sampling sites except the Control site (CS30) had no significant difference at $\alpha=0.05, \mathrm{~N}=7$ (Table 1). Each of the source points discharged significant levels of $\mathrm{NO}_{3}$ nutrients into the creek waters through surface runoff and/or leaching processes.

\subsection{Variations in the Levels of Phosphates}

There was a sporadic temporal variation in the $\mathrm{PO}_{4}^{+}$nutrients levels (Table 2) with four (4) of the sites (S25, S26, S28 and S29) showing decreasing trend during the rainy season between June and August. This depicts the fact that the pollutants are discharged into the creek by surface runoff from the source points. It suggests that runoff water from the farms and the decomposition and mineralization of organic matter had an influence on the levels of phosphates on the creek waters. Sites S24 and S27 showed slight increase in the nutrient levels. The month of October depicted the lowest levels of $\mathrm{PO}_{4}^{+}$in all the station throughout the study period. Stations S25, S26 and S28 showed an increase in the nutrients levels between September and November depicting increased anthropogenic activities at the nutrient source. Site S28 recorded the highest levels of phosphates (Table 2). Detergents which are important ingredients of phosphates seem to be frequently used for showering in the Prison, increasing the levels of the nutrients in the waste water released into the creek.

\begin{tabular}{|c|c|c|c|c|c|c|}
\hline Site & June & July & August & September & October & November \\
\hline S24 & $0.704^{\mathrm{b}}$ & $0.849^{b}$ & $0.994^{\mathrm{b}}$ & $0.820^{\mathrm{b}}$ & $0.646^{\mathrm{b}}$ & $0.675^{\mathrm{b}}$ \\
\hline S25 & $0.749^{b}$ & $0.845^{\mathrm{b}}$ & $0.940^{\mathrm{b}}$ & $0.856^{\mathrm{b}}$ & $0.772^{\mathrm{b}}$ & $0.760^{\mathrm{b}}$ \\
\hline S26 & $0.584^{\mathrm{b}}$ & $0.852^{\mathrm{b}}$ & $1.120^{\mathrm{b}}$ & $0.932^{\mathrm{b}}$ & $0.744^{\mathrm{b}}$ & $0.664^{\mathrm{b}}$ \\
\hline S27 & $0.615^{\mathrm{b}}$ & $0.885^{\mathrm{b}}$ & $1.154^{\mathrm{b}}$ & $0.882^{\mathrm{b}}$ & $0.610^{\mathrm{b}}$ & $0.612^{\mathrm{b}}$ \\
\hline S28 & $0.698^{\mathrm{b}}$ & $0.739^{\mathrm{b}}$ & $0.780^{\mathrm{ab}}$ & $0.699^{\mathrm{b}}$ & $0.618^{\mathrm{b}}$ & $0.658^{\mathrm{b}}$ \\
\hline S29 & $0.553^{\mathrm{b}}$ & $0.690^{\mathrm{b}}$ & $0.826^{\mathrm{b}}$ & $0.771^{\mathrm{b}}$ & $0.715^{\mathrm{b}}$ & $0.633^{\mathrm{b}}$ \\
\hline SC30 & $0.244^{\mathrm{a}}$ & $0.261^{\mathrm{a}}$ & $0.245^{\mathrm{a}}$ & $0.271^{\mathrm{a}}$ & $0.255^{\mathrm{a}}$ & $0.240^{\mathrm{a}}$ \\
\hline
\end{tabular}

Note: Mean values in each column with the same letter are not significantly different at $\alpha=0.05$.

Table 2. Levels of $\mathrm{PO}_{4}^{-} \quad$ ( $\mu$ gat $\mathrm{P} / \mathrm{L}$ ), from June to November 2011.

\begin{tabular}{ccccccc}
\hline Site & June & July & August & September & October & November \\
\hline S24 & $0.555^{\mathrm{a}}$ & $0.704^{\mathrm{a}}$ & $0.852^{\mathrm{a}}$ & $0.870^{\mathrm{a}}$ & $0.889^{\mathrm{a}}$ & $0.722^{\mathrm{a}}$ \\
S25 & $1.019^{\mathrm{a}}$ & $1.009^{\mathrm{ab}}$ & $1.000^{\mathrm{a}}$ & $0.935^{\mathrm{a}}$ & $0.870^{\mathrm{a}}$ & $0.945^{\mathrm{a}}$ \\
S26 & $1.444^{\mathrm{ab}}$ & $1.222^{\mathrm{abc}}$ & $1.000^{\mathrm{a}}$ & $0.843^{\mathrm{a}}$ & $0.685^{\mathrm{a}}$ & $1.065^{\mathrm{ab}}$ \\
S27 & $0.908^{\mathrm{a}}$ & $0.917^{\mathrm{a}}$ & $0.926^{\mathrm{a}}$ & $0.889^{\mathrm{a}}$ & $0.851^{\mathrm{a}}$ & $0.880^{\mathrm{a}}$ \\
S28 & $2.241^{\mathrm{b}}$ & $1.565^{\mathrm{c}}$ & $0.889^{\mathrm{a}}$ & $0.889^{\mathrm{a}}$ & $0.889^{\mathrm{a}}$ & $1.565^{\mathrm{b}}$ \\
S29 & $1.611^{\mathrm{ab}}$ & $1.306^{\mathrm{c}}$ & $1.000^{\mathrm{a}}$ & $0.907^{\mathrm{a}}$ & $0.814^{\mathrm{a}}$ & $1.213^{\mathrm{ab}}$ \\
SC30 & $0.770^{\mathrm{a}}$ & $0.960^{\mathrm{a}}$ & $0.871^{\mathrm{a}}$ & $0.895^{\mathrm{a}}$ & $0.888^{\mathrm{a}}$ & $0.876^{\mathrm{a}}$ \\
\hline
\end{tabular}

Note: Mean values in each column with the same letter are not significantly different at $\alpha=0.05$. 
The levels of Phosphates along Mtwapa creek were significantly difference in each site throughout the study period with seasonal fluctuations indicating differences in the biological utilization among the stations.

\subsection{Variations in the Levels of Ammonia}

The Creek waters recorded high levels of the ammonia nutrients ranging from $23.065 \mu$ gat $\mathrm{NH}_{3} / \mathrm{L}$ at Site S28 to $0.584 \mu$ gat $\mathrm{NH}_{3} / \mathrm{L}$ recorded at site S25 (Table 3). Site S28 recorded high levels of ammonium ranging from $23.065 \mu$ gat $\mathrm{NH}_{3} / \mathrm{L}$ in June to $1.792 \mathrm{Mg} / \mathrm{L}$ in August (Table 3). October depicted high levels of ammonium throughout the study sites probably due to high tourist activities in the month generating ammonia loaded wastes. The Control site (SC30) had consistently low and moderate levels of ammonia, indicating insignificant levels of biological contaminants offshore (Table 3). However, the high variations in the levels of the nutrients were not significantly different in August, September and October 2011. The presence of high and sporadic ammonia levels is evident of untreated sewage and waste water discharged into the creek from the different sources.

\subsection{Rate of Carbon Assimilation}

Carbon assimilation denoting the Primary productivity on the creek was calculated as the difference between photosynthesis and respiration using the Winkler method. The levels of carbon assimilation in the creek waters ranged between $0.983 \mathrm{mgC} / \mathrm{L}$ recorded at S24 in November to $0.103 \mathrm{mgC} / \mathrm{L}$ at S25 recorded in August. The nutrients levels were slightly high at station S27, S28 and S29 throughout the study period (Table 4), while it was lowest at the Control site SC30. Station S26 also recorded low carbon values throughout between June and November 2011. This suggests a more phytoplankton activities in areas with high carbon assimilation. The variations in the rate of assimilation were distinct between sites and season depicting the nature and means of discharge of the nutrients into the creek water.

\subsection{Correlation Coefficient between Nutrients and Carbon}

The correlation coefficients are as shown in Table 5. Along Mtwapa creek, Nitrate nitrogen, the element which mostly limits primary production in the ocean, showed negative correlation in all stations except S26 and S27.

Phosphates nutrients showed unclear trends with regard to nutrient and productivity levels with correlation factor ranging from $r=-0.886$ to $r=+0.947$ recorded at S26 and S27. The source point at S26 discharges waste that kills some phytoplankton species reducing primary productivity in the creek waters, while site S27 had a phytoplankton species that take up phosphates for vital for increased primary production. However, Phosphorous is second limiting nutrient in marine systems occurring in diversified range of organic compounds which can be broken down by enzymes that are located in the membranes of many algal species. Ammonia showed negative correlation with carbon assimilation within the outer stations including S27, S28 and S29 ranging from $r=-0.831$ to $r=-0.295$. This implies ammonium discharge inhibit photosynthesis and consequently the primary production in the creek waters. The positive correlation factor implies the source points have algal species that assimilate ammonium for photosynthesis. Nitrates also depicted negative and positive relationships similar

Table 3. Levels of $\mathrm{NH}_{3}$ ( $\mu$ gat $\mathrm{NH}_{3} / \mathrm{L}$ ) from June to November 2011.

\begin{tabular}{ccccccc}
\hline Site & June & July & August & September & October & November \\
\hline S24 & $1.063^{\mathrm{a}}$ & $1.219^{\mathrm{ab}}$ & $1.375^{\mathrm{a}}$ & $1.802^{\mathrm{a}}$ & $2.229^{\mathrm{b}}$ & $1.646^{\mathrm{a}}$ \\
S25 & $0.584^{\mathrm{a}}$ & $1.146^{\mathrm{ab}}$ & $1.709^{\mathrm{a}}$ & $2.615^{\mathrm{ab}}$ & $3.521^{\mathrm{b}}$ & $2.052^{\mathrm{a}}$ \\
S26 & $0.688^{\mathrm{a}}$ & $1.000^{\mathrm{a}}$ & $1.313^{\mathrm{a}}$ & $1.844^{\mathrm{a}}$ & $2.375^{\mathrm{b}}$ & $1.532^{\mathrm{a}}$ \\
S27 & $0.729^{\mathrm{a}}$ & $1.104^{\mathrm{ab}}$ & $1.479^{\mathrm{a}}$ & $1.938^{\mathrm{a}}$ & $2.396^{\mathrm{b}}$ & $1.563^{\mathrm{a}}$ \\
S28 & $23.065^{\mathrm{b}}$ & $12.428^{\mathrm{c}}$ & $1.792^{\mathrm{a}}$ & $2.375^{\mathrm{ab}}$ & $2.959^{\mathrm{b}}$ & $13.012^{\mathrm{b}}$ \\
S29 & $1.771^{\mathrm{a}}$ & $1.532^{\mathrm{ab}}$ & $1.292^{\mathrm{a}}$ & $1.761^{\mathrm{a}}$ & $2.229^{\mathrm{b}}$ & $2.000^{\mathrm{a}}$ \\
SC30 & $1.123^{\mathrm{a}}$ & $1.286^{\mathrm{b}}$ & $1.258^{\mathrm{a}}$ & $1.511^{\mathrm{a}}$ & $1.938^{\mathrm{a}}$ & $1.130^{\mathrm{a}}$ \\
\hline
\end{tabular}

Note: Mean values in each column with the same letter are not significantly different at $\alpha=0.05$. 
Table 4. Rate of carbon assimilation (mgC/L), levels from June to November 2011.

\begin{tabular}{ccccccc}
\hline Site & June & July & August & September & October & November \\
\hline S24 & $0.367^{\mathrm{ab}}$ & $0.243^{\mathrm{abc}}$ & $0.120^{\mathrm{ab}}$ & $0.860^{\mathrm{d}}$ & $1.600^{\mathrm{c}}$ & $0.983^{\mathrm{c}}$ \\
S25 & $0.360^{\mathrm{ab}}$ & $0.230^{\mathrm{a}}$ & $0.103^{\mathrm{a}}$ & $0.230^{\mathrm{b}}$ & $0.360^{\mathrm{b}}$ & $0.360^{\mathrm{b}}$ \\
S26 & $0.136^{\mathrm{a}}$ & $0.140^{\mathrm{a}}$ & $0.150^{\mathrm{b}}$ & $0.150^{\mathrm{a}}$ & $0.150^{\mathrm{a}}$ & $0.140^{\mathrm{a}}$ \\
S27 & $0.330^{\mathrm{ab}}$ & $0.330^{\mathrm{bc}}$ & $0.330^{\mathrm{c}}$ & $0.323^{\mathrm{c}}$ & $0.320^{\mathrm{b}}$ & $0.323^{\mathrm{b}}$ \\
S28 & $0.340^{\mathrm{ab}}$ & $0.353^{\mathrm{bc}}$ & $0.370^{\mathrm{c}}$ & $0.383^{\mathrm{c}}$ & $0.400^{\mathrm{b}}$ & $0.370^{\mathrm{b}}$ \\
S29 & $0.450^{\mathrm{b}}$ & $0.393^{\mathrm{c}}$ & $0.343^{\mathrm{c}}$ & $0.343^{\mathrm{c}}$ & $0.343^{\mathrm{b}}$ & $0.393^{\mathrm{b}}$ \\
SC30 & $0.137^{\mathrm{ab}}$ & $0.130^{\mathrm{a}}$ & $0.170^{\mathrm{a}}$ & $0.132^{\mathrm{a}}$ & $0.140^{\mathrm{a}}$ & $0.141^{\mathrm{a}}$ \\
\hline
\end{tabular}

Note: Mean values in each column with the same letter are not significantly different at $\alpha=0.05$.

Table 5. Correlation between mean levels of nutrients and rate of carbon assimilation from June to November 2011.

\begin{tabular}{cccc}
\hline Station & $\mathrm{NO}_{3}^{-}$ & $\mathrm{PO}_{4}^{-}$ & $\mathbf{N H}_{3}$ \\
\hline $\mathrm{S} 24$ & -0.742 & 0.451 & 0.914 \\
$\mathrm{~S} 25$ & -0.994 & -0.393 & 0.1337 \\
$\mathrm{~S} 26$ & 0.7105 & -0.886 & 0.761 \\
$\mathrm{~S} 27$ & 0.495 & 0.947 & -0.831 \\
$\mathrm{~S} 28$ & -0.506 & -0.857 & -0.831 \\
$\mathrm{~S} 29$ & -0.624 & 0.869 & -0.295 \\
$\mathrm{~S} C 30$ & -0.517 & -0.186 & -0.141 \\
\hline
\end{tabular}

to the other nutrients. In the oligotrophic deep ocean sites (SC30) there seem to be little input of fresh nitrates into the upper mixed layer from below and the values are normally very low below $0.1 \mu \mathrm{mol} \cdot \mathrm{L}^{-1}$. The difference in correlation coefficient implies the creek has different algal species that take different levels of nutrients for productivity. Ammonia in sea water exists as a mixture of ammonium ions and ammonia.

\section{Discussion}

\subsection{Nutrients Levels}

The sensitivity of phytoplankton production and or composition in a marine ecosystem is controlled by light, circulation patterns and availability of nutrients discharges in the aphotic zone. Other environmental conditions such as the $\mathrm{pH}$ and temperature changes in the water column affect the taxonomic composition of the phytoplankton communities, cell abundance and species richness during annual seasonal cycles [11]. The net primary production of photoautotrophs in the ocean depends on amount of nutrient discharges with some nutrients limiting production of phytoplankton biomass in a system at a given time. The water quality in marine regions can directly or indirectly be adversely affected by land-based and water-based anthropogenic activities with most of the pollutants find their into the marine environment from land-based activities through sewerage drainage system, leaching and draining of agricultural fertilizers and animal feeds or discharge of poorly or untreated wastewater. These activities may result in elevated nutrient, mostly nitrogen and phosphorus, concentrations leading to eutrophication and decline in primary productivity. The increase in toxic algal blooms may cause death of benthic fauna, threat to human life and may have negative aesthetical impacts limiting recreational activities [11].

The variations in the nutrients levels in the study area were distinct and the results confirm that different source point discharges different types of nutrients. It is observed that open ocean waters are not significantly influenced by either the human disturbances along neither the creeks nor the amounts of runoff waters into the creek waters [12]. The nutrients discharge in the creek are attributed to the anthropogenic activities which in- 
clude urban development, in-water activities such as fishing and boat repairs as well as the subsistence farming along the creek banks. The results prove that rivers and runoff water convey terrestrially derived materials loaded with sewage, agricultural and industrial pollutants. Waste water and surface runoff from urban and tourist developments contribute to input of phosphates into marine waters [13]. Further offshore, the direct human influence is limited, and therefore lacks some major pollutants. The decreased influence of human activities with distance from the coastline is related to physical limitation imposed by water circulation pattern and the transportation processes [13]. Nitrates are the primary source of nitrogen utilized by algae, although Nitrites and Ammonium ions can also be taken up [13]. Some cynobacteria such as Trichodemium spp. can however fix (reduce) nitrogen gas where other forms of nitrogen are limited. The findings reveal that the higher fertility levels in the upstream creek waters influenced the rate of photosynthetic activity among the phytoplankton cells in addition to decay and decomposition of these cells [13]. The open ocean waters revealed close to zero correlation between nutrients and carbon which could be attributed to either low biological activity or dilution of the creek water as it mixes with the water from the open ocean. Other chemical and physical properties of the water including turbidity and dissolved oxygen however also have an influence on the rate of photosynthesis.

\subsection{Carbon Assimilation Correlations}

Phosphorous is second limiting nutrient in marine systems and occurs in several forms. It is also present in a diverse range organic compounds which can be broken down by enzymes that are located in the membranes of many algal species. Ammonia showed negative correlation with carbon assimilation within the outer stations and the inner station creek stations however all showed positive correlation with carbon assimilation. Ammonia in sea water exists as a mixture of ammonium ions and ammonia [13]. In the oligotrophic deep ocean sites there seem to be little input of fresh nitrates into the upper mixed layer from below and the values are normally very low below $0.1 \mu \mathrm{mol} \cdot \mathrm{L}^{-1}$. In the coastal sites, coastal upwelling can result into high input of nitrates and the f-ratio (ratio between new and recycled production) can be as high as $0.8 \mu \mathrm{mol} \cdot \mathrm{L}^{-1}[13]$.

\subsection{Management of Nutrients Discharge}

The nutrients load in the creek waters are significantly high and are likely to affect both human and the marine flora and fauna, thus strategic management approaches need to be put in place to control pollution and intoxication of the aquatic organisms. The management strategies are to support practical, sustainable and legal management of nutrient discharge into the marine environment. Several methodologies have been developed to minimize nutrients discharge including developing land-based buffer zones along flow paths [14]. Encouraging eco-friendly and cost-effective technologies and creating awareness and building capacity towards wastewater management are some of the strategies control effluent discharge [15]. Efforts have been made to address land based activities by formulating Strategic Action Plans (SAP) to address challenges of increased coastal water pollution in the Western Indian Ocean region [8]. Direct toxicity assessment (DTA) or Whole Effluent Toxicity (WET) testing as an integral part of the regulatory framework in many countries is used to assess and manage effluents, leachates and contaminated ambient waters in marine and freshwater environments. DTA can serve as an early warning for the implementation of management actions and also to provide a direct measure of toxicity and bioavailability of mixtures whose chemical composition is not known. Common regulatory microbial indicators of fecal pollution include Escherichia coli and Enterococcus spp. [16]. Despite the creation of national institutions and the enactment of national laws supported by international conventions, the management of the coastal and marine environment is still a challenge. Kenya, like most countries, has put in place policy, legal, regulatory and institutional frameworks aimed at protecting and managing the coastal environment [7].

\section{Conclusion}

The findings of this study suggest that there are higher levels of phytoplanktonic activities in the outer creek compared with the inner creek. The levels of phosphates at these sites showed a strong positive correlation with carbon assimilation and were generally higher in all these three stations compared with the inner stations. These findings reveal that the higher fertility levels of the outer creek waters influenced the rate of photosynthetic activity among the phytoplankton cells. Nitrate, which mostly limits primary production in the ocean, shows negative correlation in all stations except S29 and S36. Nitrates are the primary source of nitrogen utilized by algae, 
although Nitrites and Ammonium ions can be taken up [12]. The study recommends that a continuous monitoring of waste water and sewage treatment facilities and land-based activities which impact negatively on coastal marine ecosystems be undertaken. Awareness creation should be encouraged with alternative solid waste strategies such as bagging of solid waste instead of flushing them into water ways among communities living close to the creeks. Currently there is a lack of clear boundary extent of beaches in Kenya, together with an ambiguous legislation governing the development of structures along the shoreline; there is a need for appropriate coastal planning and development guidelines under an enforced Integrated Coastal Zone Management (ICZM) plan. Traditional farming practices need to be replaced with better soil management and water-use methods and other land-based activities to avoid pollution of the creek waters.

\section{Acknowledgements}

We acknowledge the Deans committee at Pwani University through the Pwani University Research Board for awarding us a grant that enabled us to carry out this research.

\section{References}

[1] Stuart, D. (2010) Coastal Ecosystems and Agricultural Land Use: New Challenges on California’s Central Coast, Coastal Management. Environmental Resources Journal, 38, 42-64. http://dx.doi.org/10.1080/08920750903363190

[2] Mwamuye, P. (2015) Impact of Nutrients on Phytoplankton Productivity of the Coastal Marine Waters of Mtwapa, Mida and Kilifi Creeks, Kilifi County. Master’s Thesis, Kenyatta University, Kenya.

[3] SCECAP (2010) Estuarine Condition Monitoring and Assessments. Marine Resources Division, South Carolina, Department of Natural Resources, Charleston.

[4] Jay, A.B., Ingall, E. and Paterson, D. (2007) Characterization of Minerals and Organic Phosphorus Species in Marine Sediments Using Soft X-Ray Fluorence Spectromicroscopy. Marine Chemistry, 1, 250-265.

[5] Okuku, E.O., Ohowa, B., Mwangi, S.N., Munga, D., Kiteresi, L.L., Wanjeri, V.O., Okumu, S. and Kilonzo, J. (2010) Sewage Pollution in Coastal Waters of Mombasa City: A Norm Rather than an Exception. Environmental Resources, 5, 865-874.

[6] KEMFRI (2013) Characterization of Nutrient Enrichment in the Estuaries and Related Systems in Kenya Coast. Environmental Resources Journal (Online), 2, 181-190.

[7] UNEP (2009) Strategic Action Programme for the Protection of the Coastal and Marine Environment of the Western Indian Ocean from Land-Based Sources and Activities. Nairobi, Kenya.

[8] Hogarth, P.J. (1998) The Biology of Mangroves. Crawley, M.J., Little, C., Southwood, T.R.E. and Ulfstrand, S., Eds., Oxford Ox ${ }^{2}$ 6DP, Great Clarendon Street, New York.

[9] Siokou-Frangou, I. and Pagou, K. (2000) Assessment of the Trophic Conditions and Ecological Status in the Inner Saronikos Gulf. Technical Report for the Ministry of Environment, Planning and Public Works, NCMR, Athens, 43.

[10] APHA American Public Health Association (1995) Standard Methods for Examination of Water and Waste Water. 18th Edition, APHA, Washington DC.

[11] Moreno-Díaz1, G., Rojas-Herrera, A.A., Violante-González, J., González-González1, J., Acevedo1, J.L. and Ibáñez, S.G. (2015) Temporal Variation in Composition and Abundance of Phytoplankton Species during 2011 and 2012 in Acapulco Bay, Mexico. Open Journal of Marine Science, 5, 358-367. http://dx.doi.org/10.4236/ojms.2015.53029

[12] Kaiser, M.J., Attril, M.J., Jennings, S., Thomas, N.D., Barnes, D.K.A., Brierly, S.A., Polunin, N.V.C., Raffaelli, D.G. and LeB Williams, P.J. (2005) Marine Ecology: Processes, Systems and Impacts. Oxford University Press Inc., New York.

[13] Bizsel, N. and Uslu, O. (2000) Phosphates, Nitrogen and Iron Enrichment in the Polluted Izmir Bay, Aegean Sea. Marine Chemistry, 7, 317-324. http://dx.doi.org/10.1016/s0141-1136(99)00051-3

[14] Weller, D.E., Baker, M.E. and Jordan, T.E. (2011) Effects of Riparian Buffers on Nitrate Concentrations in Watershed Discharges: New Models and Management Implications. Ecological Applications, 21, 1679-1695. http://dx.doi.org/10.1890/10-0789.1

[15] Benard, O. and Omondi, G. (2012) Wastewater Production, Treatment, and Use in KENYA. Third Regional Workshop 'Safe Use of Wastewater in Agriculture', Johannesburg, 26-28 September 2012.

[16] USEPA United States Environmental Protection Agency (2004) Water Quality Standards for Coastal and Great Lakes Recreation Waters. Final Rule, 40 CFR Part 131. www.epa.gov/EPA-WATER/2004 